\title{
Measuring Job Satisfaction Patterns in Saudi Arabia's Southern Regions Hospitals: Implications for Hospital Staff Retention
}

\author{
Alshahrani Bander Sayaf \\ Dental department, Armed Forces Hospital, Sharurah city, Saudi Arabia \\ Corresponding author (e-mail): b-sayyaf@hotmail.com
}

\begin{abstract}
Saudi Arabia Southern Region hospitals have shortage of health professionals especially doctors. Retention of quality doctors and minimizing staff turnover has, therefore, become a major priority for hospitals. Job satisfaction is recognized as key factor influencing retention of doctors. In our paper special emphasis is put on doctors working is Southern Region hospitals of Saudi Arabia. By conducting correlation analysis we determine the most important factors conducive to job satisfaction. Results of the study indicate that opportunities for promotion have a strong link with job satisfaction, whereas relations with co-workers and attitude toward supervisor exhibited a moderately strong relationship with job satisfaction. The factors of nature of the work, compensations and benefits lack a significant link to overall job satisfaction. The findings imply that the health care service managers need to pay closer attention to the needs of their human resources, especially doctors, in order to not only minimize the doctors turnover but also to improve the organizations' performance. Additionally, introducing turnover risk programs as well as employee satisfaction programs within the hospital's management schemes have become a must. Saudi Arabian hospitals, especially those in the Southern Region, can make use of retention strategies to annihilate the unbalance caused by the doctors' high turnover.
\end{abstract}

Key words: Job satisfaction, Doctors retention strategies, Hospital staff turnover, Saudi Arabia, Health care

\section{Introduction}

Human resource management has been recognized as an important driver of organizations competitive advantage and market success, and is playing an important role in the global business arena (Florkowski and Schuler 1994). Prior studies have shown that human resource practice has a significant link to measures of 
perceptual firm performance (Delane et al. 1996), operational measures of performance, operating expenses, pre-tax profits and other work related outcomes (Wright et al. 2003, Boselie et al. 2005, Guest 2002, Obrenovic et al. 2014).

Given the importance HRM plays in the success of organizations, one may ask himself why the field of HRM is often being ignored by the policy makers and organization leaders. In our study we examine HRM related factors in the context of Saudi Arabian healthcare sector as well as their importance in boosting employee satisfaction and minimizing the hospital staff turnover rates. In fact, the Saudi Arabian government has exerted significant effort in the last 15 years to regulate the labor market and support human resource management functions in the private sector (Mellahi 2007). However, an overall human resources development drawback still exists in Saudi Arabia. The underlying causes of this phenomenon pertain to high dependence on foreign labor force and high dependence on the petrochemical and oil industry. Moreover, the education system does not generate adequately skilled labor force required by the economic sector, indicating that human resource management development may be constrained by the labor market distortion and the social values (Mellahi 2000, Achoui 2009). For instance, another issue is a low level of participation of women in the overall employment of the country

The health sector is a part of economy and social sector that has undergone huge improvements in Saudi Arabia. (Berhie 1991). However, a severe shortage of well-trained manpower and staff turnover has been identified by the Saudi Arabian government as a major weak point of the health sector (Berhie 1991). Inability to find and retain adequate talent of strategic importance is a significant impediment for organizations' growth (Ready and Conger 2007), given that recruiting and training new talent or finding a replacement require lots of resources. That is to say that turnover has a negative impact on the productivity and the morale of the company (Zeynep and Huckman 2008).

Various factors such as low salary, poor working conditions, dismissal and resignation may cause high staff turnover. There is not enough facility for inner medical information system and the workshops and training programs are very scarce. In fact, the shortage of doctors in hospitals has led to other related impediments such as lack of timely medical services and extra working hours. Excessive workloads affect the work/life balance resulting in doctors' general dissatisfaction and sometimes even causing the family life to suffer given that the majority of doctors in Saudi Arabia are married and have children.

The purpose of our investigation is to identify the working environment in which the doctors in Saudi Arabia Southern region hospitals are exercising their job. In addition, we intended to gather information relative to the management of the hospitals, the problems they face, and above all, the instability problems caused by the many doctors who cannot afford staying at the remote region of the South. As there is little work oriented on the specific case of Southern Region hospitals in the Kingdom of Saudi Arabia we chose to do exploratory research. Most of the existing literature examines macroeconomic features relative to the healthcare policies and systems in Saudi Arabia. Therefore, in this paper we investigate human resource 
management role in the health care institutions of Saudi Arabia by examining factors conducive to doctors' job satisfaction which have implications for hospital staff turnover rates and doctors' retention. In the initial section we set up a theoretical framework for the analysis of each factor related to job satisfaction that may play an important role in affecting doctors' turnover rates. Next, the research methods employed in this study are described followed by the presentation of the results. Based on the discussion of our findings we propose several major winning strategies designed to solve Saudi Arabian Southern region doctors' high turnover equation.

\section{Literature review and research concept construction}

Prior studies have identified a significant impact of job satisfaction on hospital staff turnover and doctors' intention to stay (Hom and Kinicki 2001, Coomber and Barriball 2007, Gilles et al. 2014, Lam et al. 2001). A research by Lucy Firth et al. (2004) suggested that high turnover could be reduced by actively monitoring workloads and the relationships between supervisors and subordinates. In addition, managers should manage both intrinsic and extrinsic drivers of job satisfaction that reduce stress and increase commitment to the organization. Another study by Thomas et al. (2012) on the relationships between licensed nurse retention, turnover, and a 30-day re-hospitalization rate, suggested that since a stable set of nursing personnel is more keen on delivering better health care, policy-makers should favor and focus on the retention of the licensed nurses. Other studies in the healthcare context have demonstrated the link between job satisfaction and the quality of care provided. Evidence suggests that, for instance, that good HRM makes the difference in the hospital's setting (Buchan, 2008), and even reduces mortality (West et al. 2006, Aiken et al. 2002). Consequently, increasing job satisfaction has become one of the priorities of the HR departments whereas the research community has spent a lot of effort researching factors that contribute and enhance job satisfaction.

\subsection{Increasing employee satisfaction}

An organization's staff is more than just employees. They represent, in fact, the single most valuable asset within the organization. As a widespread theory, it is believed that in general, satisfied employees perform their job more effectively than unsatisfied ones (Shipton et al. 2006). This theory is known as the 'happyproductive worker hypothesis' (Fisher, 2003). However, it is a challenge assessing job satisfaction given that employees can be satisfied with some aspects of their job, and at the same time dissatisfied with other facets of the job (Spagnoli et al. 2012). Their retention can be successful if the organization succeeds in making changes in the aspects of the job they are dissatisfied with. It is quite evident that job satisfaction is a multifaceted phenomenon. Hee Yoon et al. (2004) identify three organizational antecedents of employee satisfaction and employee customer service. They are as follows: perceived organizational support, perceived supervisory support and customer participation.

31

ISSN 1849-5664 (online) http://researchleap.com/category/international-journal-of-management-science-and-business-administration ISSN 1849-5419 (print) International Journal of Management Science And Business Administration Vol 1. No 3. February 2015., pp. 29-49 
In our study we have however, employed Job Descriptive Index (JDI), measuring employee job satisfaction patterns. These patterns encompass nature of the work, compensations and benefits, attitudes towards supervisors, relations with co-workers and opportunities for promotion. We, therefore, use existing framework to determine the relationship between these patterns and Saudi Arabia South Region doctors' job satisfaction levels.

\subsubsection{Attitude towards supervisor and job satisfaction}

Prior studies indicate that poor leadership, management style and leader characteristics are significant contributing factors to dissatisfaction of hospital workers (Coomber and Barriball 2007, Champathes, Rodsutti and Swierczek 2002). Conversely, when the leader is perceived to exhibit consultative or participative leadership behavior, employees tend to be more satisfied with their jobs, with higher levels of organizational commitment as well as work performance (Yousef 2000).The direct treatment by their managers and the extent to which they were informed about decisions and changes have a strong link with job satisfaction (McAuliffe et al. 2009). The supervisory support reflects a climate of trust, helpfulness, and friendliness between the supervisors and the subordinates (Hee Yoon et al. 2004). A high perceived supervisory support implies that important socio-emotional taxonomies are running well in the work environment and enables the formation of positive attitude toward supervisor.

Given all the evidence we hypothesize:

Hypothesis 1 There is a significant relationship between attitude toward the supervisor and job satisfaction of hospital workers in Saudi Arabia

\subsubsection{Salary, benefits and job satisfaction}

According to Adam's equity theory, people have different ways of removing a sensed discomfort or inequities in their work to restore it with a state of felt equity to the situation. They can do so by changing the work inputs, changing the rewards received, leaving the situation, or changing the comparison elements. As a result, people who feel overpaid (a feeling of positive inequity) tend to increase the quantity or quality of their work whereas people who are underpaid (a feeling of negative inequity) tend to do the contrary. This is a mean to explain that 'salary' can be a crucial source of motivation and job satisfaction (Lim 2008), though many researchers, including the motivation theorist Herzberg, believe that money is not a primary motivator as it has only partially showed significance in influencing job satisfaction (Judge et al. 2010). The latter consider that focusing on how people feel about their work itself is likely the most effective way to motivate work behavior.

Consequently, additional instruments are designed in order to generate the required motivation. In various studies a clear link was confirmed between rewards (Bustamam et al. 2014), recognition systems and job satisfaction, which in turn influences employee retention (Eisenberger et al. 2002).

32

ISSN 1849-5664 (online) http://researchleap.com/category/international-journal-of-management-science-and-business-administration ISSN 1849-5419 (print) International Journal of Management Science And Business Administration Vol 1. No 3. February 2015., pp. 29-49 
Hypothesis 2 There is a significant relationship between salary, rewards and job satisfaction of hospital workers in Saudi Arabia

\subsubsection{Nature of the work and job satifaction}

Whether the job itself is meaningful and well organized is an important driver of worker motivation, as well as their job satisfaction (Hauff et al. 2015). How much freedom the doctors have and whether they spend their time meaningfully treating patients as their job description implies or spend their time on administrative tasks, as a result of understaffing, is a significant determinant in their level of satisfaction. In hospitals where staff turnover and lack of adequate talent is a pertaining problem doctors are usually required to take on extra work, either in terms of patient care or administration. This, in turn, leads to increased job dissatisfaction. On the other hand, increased job variety, job autonomy and feedback have an enhancing effect on job satisfaction (Katsikea et al. 2011, Pan 2015). According to Pan, F. C. (2015), when workers are free to decide how to develop and organize their own work they often feel more satisfied and committed to their job. In the study of nature of commitment and job satisfaction, and job characteristics of 504 expatriates living in Saudi Arabia a significant impact of job satisfaction on commitment was determined. Furthermore, a strong link between job variety, job autonomy and feedback to job satisfaction was revealed (Bhuian et al. 1996). As hospitals in the Southern region of Saudi Arabia have high turnover and understaffing problems we deduce the following:

Hypothesis 3 There is a significant relationship between nature of work and job satisfaction of hospital workers in Saudi Arabia

\subsubsection{Relationships with co-workers and job satisfaction}

As people are social beings, one important part of the work environment is the existence of quality relationships with others. A "sense of belonging, faith in wanting to belong, and feeling of acceptance" all are conducive to fostering a feeling of job satisfaction in employees (Lim 2008). This enables a creation of social capital among workers which in turn enhances the work climate and generally makes workplace more pleasant. Social capital also has a link with job satisfaction (Flap and Völker 2001). Furthermore, a direct relationship between co-worker support and job satisfaction has already been established in other studies. (Roxana 2000, Adams and Bond).

Hypothesis 4 There is a significant relationship between relationships with co-workers and job satisfaction of hospital workers in Saudi Arabia 


\subsubsection{Job satisfaction and promotion opportunities}

Past studies have shown that, work satisfaction is associated with equal opportunities (Guest, D. 2002), especially in relation to promotion opportunities (Lim 2008). For instance, an investigation of 34 health facilities in Malawi utilized a concept of organizational justice consisting of fair procedures, communication and treatment at their workplace and showed that perceptions of justice correlated strongly with level of job satisfaction (Chaudhury and Banerjee 2004). More specifically a link between promotion opportunities and satisfaction with current work assignments was significant (McAuliffe et al. 2009). When unfair advantage is given, doctors may feel resentful, indifferent and disappointed leading toward overall job dissatisfaction. Therefore, discrimination at workplace would have adverse effects on job satisfaction.

Hypothesis 5 There is a significant relationship between the opportunities for promotion and job satisfaction of hospital workers in Saudi Arabia

In order to test the hypothesized relationship empirical investigation was planned and conducted. Further, research design and methods are described.

\section{Research methodology}

In our study we employed the explanatory approach, consisting of descriptive characteristics, in order to determine the correlation relationship between two elements as detailed by Sarmah (2013). The specific elements revolving around our subject that need to be explained involve the doctors working conditions in Southern region hospitals, the differences in management between those hospitals and the hospitals in the other cities, the reasons why there is such a high turnover rate tendency and how the doctors view their job in terms of motivation and level of satisfaction. We contrarily deepen our investigation by conducting specific observations about what countermeasures to undertake vis-à-vis the turnover issues and the crucial challenge of satisfying the patients, and the qualified staff members as well. Our specific population includes the doctors working in Southern Region hospitals. Doctors are at the focal point between the management staff and the hospital's customers. They not only enable us to measure the inner performances of the hospitals, but also they are valuable as they receive direct feedback from the patients. In addition, some doctors may be managers at the same time. This implies that they take part of the hospitals' decision-making and they are aware of the company's objectives and corporate strategies.

A survey strategy was chosen and the questionnaire consisting of both open ended questions and a 5-point Likert scale was developed by a group of experts combining the scales from prior studies. The first group of questions (closed-ended questions) consist of variables revealing basic information about the respondent's age, gender, status, annual income, details about his/her point of view on the management of the hospital, the relationship between employees themselves, and between employers and employees. The Job Descriptive Index (JDI) (Smith et al. 1969) intended to measure the employee job satisfaction patterns encompassing nature of the work, compensations and benefits, attitudes towards supervisors, relations with co-workers, opportunities for promotion together with Index of job satisfaction (Brayfield and Rothe 1951) was adopted, modified and employed in our investigation. The final group of questions (open-ended 
questions) reveals the respondent's own suggestions about how to improve the performance of hospitals, fulfill the doctors' expectations and satisfy the clientele. The questionnaire was administered in Arabic language after the back-to-back translations from English and Arabic were performed.

Next it was distributed to 100 doctors who have agreed to participate in the study. The overall sample size taken into consideration consists of 71 respondents that are all doctors currently working at Southern Region hospitals of Saudi Arabia. The missing 29 have either not submitted the questionnaire in due time or did not complete it correctly. The total number of respondents consists of 65 males (representing 92.9\%) and 5 are female doctors representing $7.1 \%$ along with 1 missing value. The table 3-1 below shows the demographic characteristics of the participants.

\begin{tabular}{|c|c|c|c|c|c|c|c|c|}
\hline \multirow{2}{*}{\multicolumn{2}{|c|}{ Characteristics }} & \multirow{2}{*}{$\begin{array}{l}\text { Male } \\
\text { (65) }\end{array}$} & \multirow{2}{*}{$\begin{array}{c}\text { Female } \\
\text { (5) }\end{array}$} & \multicolumn{2}{|c|}{$\begin{array}{l}\text { Missing } \\
\text { Value }\end{array}$} & \multicolumn{2}{|c|}{$\begin{array}{c}\text { Valid } \\
\text { Percent }\end{array}$} & \multirow[t]{2}{*}{$\begin{array}{l}\text { Total } \\
(70)\end{array}$} \\
\hline & & & & $\mathrm{N}$ & $\begin{array}{c}\text { Percen } \\
\mathrm{t}\end{array}$ & $\mathrm{N}$ & $\begin{array}{c}\text { Percen } \\
t\end{array}$ & \\
\hline Age & $\begin{array}{c}\text { Under } 21 \\
21 \text { to } 34 \\
35 \text { to } 44 \\
45 \text { to } 54 \\
55 \text { or } \\
\text { older }\end{array}$ & $\begin{array}{c}0 \\
7 \\
45 \\
8 \\
5\end{array}$ & $\begin{array}{l}1 \\
3 \\
0 \\
1 \\
0\end{array}$ & 1 & $1.4 \%$ & 70 & $98.6 \%$ & $\begin{array}{c}1 \\
10 \\
45 \\
9 \\
5\end{array}$ \\
\hline $\begin{array}{l}\text { Marital } \\
\text { Status }\end{array}$ & $\begin{array}{c}\text { Married } \\
\text { Unmarrie } \\
d\end{array}$ & $\begin{array}{c}64 \\
1\end{array}$ & $\begin{array}{l}5 \\
0\end{array}$ & 1 & $1.4 \%$ & 70 & $98.6 \%$ & $\begin{array}{c}69 \\
1\end{array}$ \\
\hline $\begin{array}{c}\text { Number } \\
\text { of } \\
\text { Children } \\
\text { Under the } \\
\text { Age of } 18\end{array}$ & $\begin{array}{l}\text { None } \\
\text { One } \\
\text { Two } \\
\text { Three } \\
\text { More }\end{array}$ & $\begin{array}{c}14 \\
8 \\
9 \\
12 \\
22\end{array}$ & $\begin{array}{l}1 \\
1 \\
3 \\
0 \\
0\end{array}$ & 1 & $1.4 \%$ & 70 & $98.6 \%$ & $\begin{array}{c}15 \\
9 \\
12 \\
12 \\
22\end{array}$ \\
\hline $\begin{array}{c}\text { Time } \\
\text { Experienc } \\
\text { e in the } \\
\text { Hospital }\end{array}$ & $\begin{array}{l}\text { Less than } \\
\text { a year } \\
1 \text { year to } \\
\text { less than } \\
2 \\
2 \text { to less } \\
\text { than } 5 \\
5 \text { to less } \\
\text { than } 10 \\
10 \text { years } \\
\text { or more }\end{array}$ & $\begin{array}{c}8 \\
19 \\
28 \\
7 \\
3\end{array}$ & $\begin{array}{l}0 \\
3 \\
2 \\
0 \\
0\end{array}$ & 1 & $1.4 \%$ & 70 & $98.6 \%$ & $\begin{array}{c}8 \\
22 \\
30 \\
7 \\
3\end{array}$ \\
\hline
\end{tabular}

Table 3-1 Characteristics of the Respondents 


\section{Data analysis and results}

\subsection{Descriptive analysis}

The data analysis was conducted by utilizing a SPSS statistical package. Descriptive analysis was found fitting to meet the research objectives of the study. As illustrated in the table below, the doctors who consider they are satisfied with the job in a general spectrum represent 68.3 of cumulative valid percentage. None of the respondents ticked the 'very dissatisfied' option. These results are very significant even though it should not be taken for granted to the extent that there are hidden patterns that may affect the employee's intention to leave their job.

\section{Respondent's Overall Job Satisfaction}

\begin{tabular}{|l|r|r|r|r|}
\hline & $\begin{array}{r}\text { Frequenc } \\
\text { y }\end{array}$ & Percent & \multicolumn{1}{|c|}{$\begin{array}{c}\text { Valid } \\
\text { Percent }\end{array}$} & \multicolumn{1}{c|}{$\begin{array}{c}\text { Cumulative } \\
\text { Percent }\end{array}$} \\
\hline $\begin{array}{l}\text { Valid } \begin{array}{l}\text { Very satisfied } \\
\text { satisfied }\end{array} \\
\text { Averagely } \\
\text { satisfied }\end{array}$ & 12 & 16.9 & 20.0 & 20.0 \\
$\begin{array}{l}\text { Rather } \\
\text { dissatisfied }\end{array}$ & 17 & 23.9 & 28.3 & 68.3 \\
$\begin{array}{l}\text { Total } \\
\text { Missi }\end{array}$ & 2 & 2.8 & 3.3 & 100.0 \\
System & 60 & 84.5 & 100.0 & \\
Total & 11 & 15.5 & & \\
\hline
\end{tabular}

Table 4-1 Descriptive Analysis of the Respondent's Overall Job Satisfaction

Generally, the HR decision makers focus on the group of employees who are rather dissatisfied in order to implement strategies that would make them change their position vis-à-vis the administration and environment in which they exercise their duty. In this case, we consider the cumulative percentage of the 3 remaining categories of people that are either 'neutral' ('averagely satisfied') or 'rather dissatisfied' and the missing value. They represent a total of $42.25 \%$, which is a critical proportion that requires further consideration. 


\subsection{The JDI model and cross tabulations}

We first made a qualitative Chi-square Test, which is meant to help the researcher to identify whether there is a significant relationship between two qualitative nominal variables. However, the test does not indicate how strong or weak these relations are. That is the reason why we have added a Phi Cramer's $V$ tabulation, which shows at which level the two variables are related. Then we made a Crosstabulation of the employee's overall job satisfaction with the 5 different elements included in the JDI model. Crosstabulation of the Overall Job Satisfaction Versus Relations with co-workers N: 60 (84.5\%); Missing: 11 (15.5\%). Pearson ChiSquare shows a significance ratio of 0.021 (< 0.05), which means that the ROJS data are significantly related with the respondent's relations with co-workers.

\section{Chi-Square Tests}

\begin{tabular}{|c|c|c|c|}
\hline & Value & Df & $\begin{array}{l}\text { Asymp. Sig. (2- } \\
\text { sided) }\end{array}$ \\
\hline Pearson Chi-Square & $23.844^{a}$ & 12 & .021 \\
\hline Likelihood Ratio & 20.216 & 12 & .063 \\
\hline $\begin{array}{l}\text { Linear-by-Linear } \\
\text { Association }\end{array}$ & 7.641 & 1 & .006 \\
\hline $\mathrm{N}$ of Valid Cases & 60 & & \\
\hline
\end{tabular}

a. 15 cells (75.0\%) have expected count less than 5 . The minimum expected count is .07 .

Table 4-2 Chi-square Test Overall Job Satisfaction Versus Relations with co-workers

The Cramer's $\mathrm{V}$ level of significance is $36 \%$, which means that the correlation between these two variables is moderately strong.

\section{Symmetric Measures}

\begin{tabular}{|ll|r|r|}
\hline & & \multicolumn{1}{|c|}{ Value } & Approx. Sig. \\
\hline Nominal by & Phi & .630 & .021 \\
Nominal & Cramer's V & .364 & .021 \\
N of Valid Cases & & 60 & \\
\hline
\end{tabular}

Table 4-3 Phi \& Cramer's V Test OJS Versus Relations with co-workers 


\begin{tabular}{|c|c|c|c|c|c|c|c|c|}
\hline \multicolumn{8}{|c|}{ Respondent's Viewpoint on His/Her Colleagues } & \multirow[b]{2}{*}{ Total } \\
\hline & & & strongl & $\begin{array}{c}\text { rathe } \\
r \\
\text { agre } \\
\text { e }\end{array}$ & $\begin{array}{c}\text { Neutr } \\
\text { al }\end{array}$ & $\begin{array}{c}\text { rather } \\
\text { disagre } \\
\text { e }\end{array}$ & \begin{tabular}{|} 
strongl \\
$y$ \\
disagre \\
e
\end{tabular} & \\
\hline \multirow{4}{*}{ 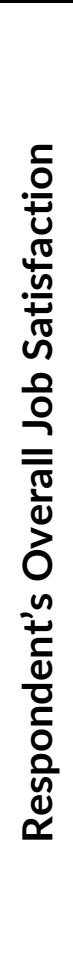 } & $\begin{array}{c}\text { very } \\
\text { satisfied }\end{array}$ & $\begin{array}{c}\text { Count } \\
\text { \% within } \\
\text { Respondent's } \\
\text { Overall Job } \\
\text { Satisfaction } \\
\text { (ROJS) }\end{array}$ & $75.0 \%$ & $\begin{array}{c}16.7 \\
\%\end{array}$ & 8.3\% & $.0 \%$ & $.0 \%$ & $100.0 \%$ \\
\hline & $\begin{array}{c}\text { rather } \\
\text { satisfied }\end{array}$ & $\begin{array}{c}\text { Count } \\
\% \text { within ROJS }\end{array}$ & $\begin{array}{c}14 \\
48.3 \%\end{array}$ & $\begin{array}{c}10 \\
34.5 \\
\%\end{array}$ & \begin{tabular}{|c|}
3 \\
$10.3 \%$ \\
\end{tabular} & $\begin{array}{c}1 \\
3.4 \%\end{array}$ & $\begin{array}{c}1 \\
3.4 \%\end{array}$ & $\begin{array}{c}29 \\
100.0 \%\end{array}$ \\
\hline & neutral & $\begin{array}{c}\text { Count } \\
\% \text { within ROJS }\end{array}$ & $\begin{array}{c}5 \\
29.4 \%\end{array}$ & $\begin{array}{c}10 \\
58.8 \\
\%\end{array}$ & $\begin{array}{c}0 \\
.0 \%\end{array}$ & $\begin{array}{c}1 \\
5.9 \%\end{array}$ & $\begin{array}{c}1 \\
5.9 \%\end{array}$ & $\begin{array}{c}17 \\
100.0 \%\end{array}$ \\
\hline & $\begin{array}{c}\text { rather } \\
\text { dissatisfi } \\
\text { ed }\end{array}$ & $\begin{array}{c}\text { Count } \\
\% \text { within ROJS }\end{array}$ & $\begin{array}{c}0 \\
.0 \%\end{array}$ & $\begin{array}{c}0 \\
.0 \%\end{array}$ & \begin{tabular}{|c|}
1 \\
$50.0 \%$
\end{tabular} & $\begin{array}{c}0 \\
.0 \%\end{array}$ & $\begin{array}{c}1 \\
50.0 \%\end{array}$ & $\begin{array}{c}2 \\
100.0 \%\end{array}$ \\
\hline & tal & $\begin{array}{c}\text { Count } \\
\% \text { within ROJS }\end{array}$ & $\begin{array}{c}28 \\
46.7 \%\end{array}$ & $\begin{array}{c}22 \\
36.7 \\
\%\end{array}$ & \begin{tabular}{|c|}
5 \\
$8.3 \%$
\end{tabular} & $\begin{array}{c}2 \\
3.3 \%\end{array}$ & $\begin{array}{c}3 \\
5.0 \%\end{array}$ & $\begin{array}{c}60 \\
100.0 \%\end{array}$ \\
\hline
\end{tabular}

\section{Crosstab}

Table 4-4 Respondent's OJS Versus Respondent's Relations with co-workers

Implications: As highlighted in blue and red, there are, in total, 10 respondents representing $16.6 \%$ within the Respondents' Overall Job Satisfaction (ROJS) who have negative scores (do not have good relations with their co-workers). Among the 10 respondents, 4 are in the 'Red Zone', meaning they have negative scores with both their overall job satisfaction and their relations with co-workers. 


\section{Chi-Square Tests}

\begin{tabular}{|c|c|c|c|}
\hline & Value & Df & Asymp. Sig. (2-sided) \\
\hline Pearson Chi-Square & $41.258^{a}$ & 12 & .000 \\
\hline $\mathrm{N}$ of Valid Cases & 59 & & \\
\hline
\end{tabular}

a. 16 cells (80.0\%) have expected count less than 5 . The minimum expected count is .07 .

Table 4-5 Chi-square Test: Respondent's OJS Versus Attitudes Towards Supervisors

(b) Crosstabulation of the Overall Job Satisfaction Versus Attitudes Towards Supervisors N: 59 (83.1\%) Missing 12 (16.9\%). The Pearson Chi-Square shows a significance ratio of 0.000 (<0.05), which means that the ROJS data are significantly correlated with the respondent's relations with co-workers. The Cramer's V level of significance is $48 \%$, which means that the correlation between these two variables is moderately significant.

\section{Symmetric Measures}

\begin{tabular}{|c|c|c|c|}
\hline & & Value & Approx. Sig. \\
\hline Nominal by & Phi & .836 & .000 \\
Nominal & Cramer's V & .483 & .000 \\
\multicolumn{2}{|c|}{ N of Valid Cases } & 59 & \\
\hline
\end{tabular}

\section{Table 4-6 Phi Cramer's V: Respondent's OJS Versus Attitudes Towards Supervisors}

Implications: As highlighted in blue and red, there are, in total, 13 respondents representing $22.1 \%$ within the Respondents' Overall Job Satisfaction (ROJS) who have negative scores (do not have good relations with their supervisors). Among them, 8 are in the 'Red Zone', meaning they have negative scores with both their overall job satisfaction and their relations with supervisors. 


\section{Crosstab}

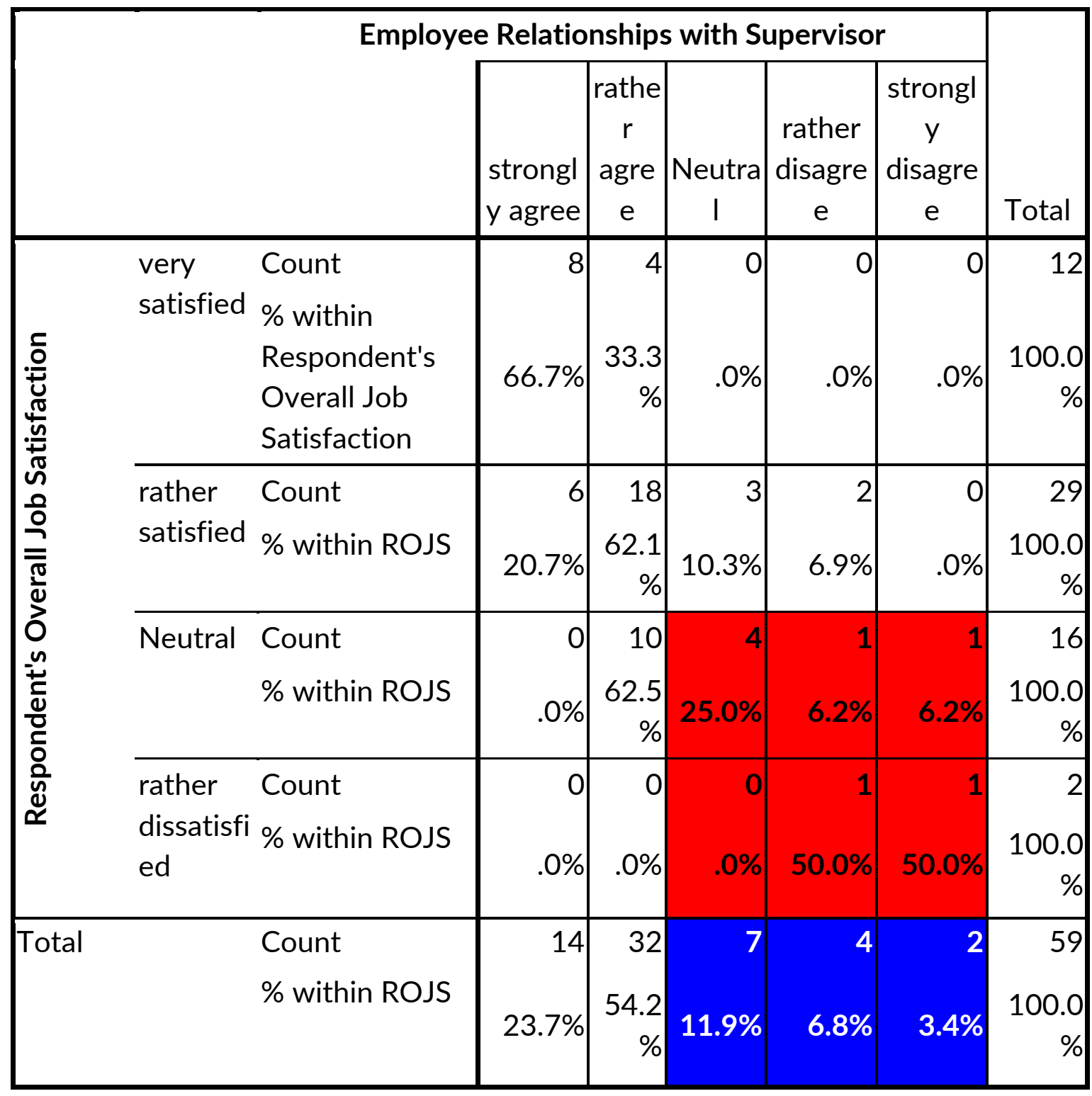

Table 4-7 Crosstab: ROJS * Employee relationship with supervisor 


\section{Bar Chart}

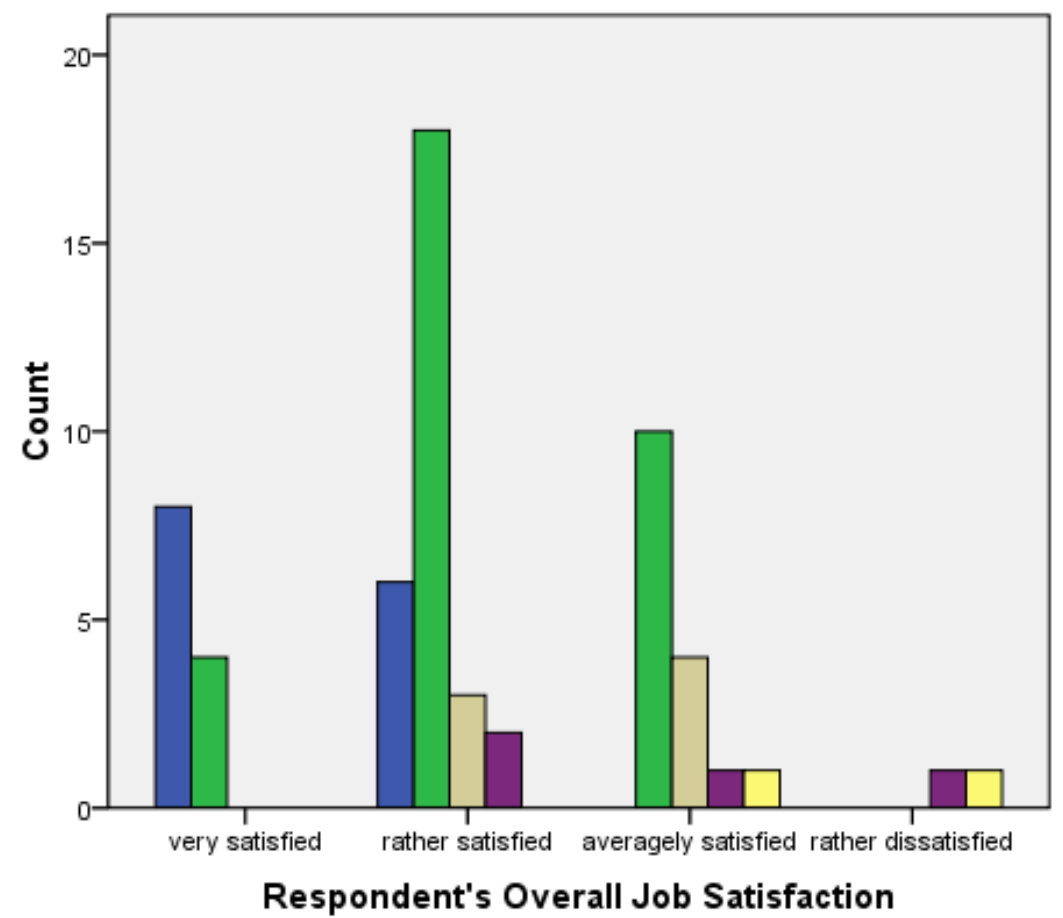

$$
\begin{gathered}
\text { Employee } \\
\text { Relationships with } \\
\quad \text { Supervisor } \\
\square \text { strongly agree } \\
\square \text { rather agree } \\
\square \text { averagely agree } \\
\square \text { rather disagree } \\
\square \text { strongly disagree }
\end{gathered}
$$

Figure 4-8 Bar Chart: ROJS * Employee relationship with supervisor

The bar chart illustrates well the dichotomies between the two types of employees we have in the hospitals. In fact, the majority of the doctors have relatively positive scores in the JDI model. However, even though they represent a small percentage in the company, serious consideration should be addressed to the respondents who are satisfied neither with their overall job satisfaction, nor with their relations with supervisors. They are represented with the purple and yellow bars in the chart.

(c) The Crosstabulation of the Overall Job Satisfaction Versus Opportunities for promotion N: 60 (84.5\%); Missing: 11 (15.5\%). The Pearson Chi-Square is significant at 0.003 (<0.05), which means that the ROJS data are significantly related with the respondent's viewpoint on the Job Promotion Features.

The Phi Cramer's V level of significance is 70\%, which means that the correlation between these two variables is very strong. Implications: There are, in total, 28 respondents, representing $46.7 \%$ within the Respondents' Overall Job Satisfaction (ROJS) who have negative scores (do not agree with the organization's promotion criteria). Among them, 13 are in the 'Red Zone', meaning they have negative scores with both the overall job satisfaction and the promotion features.

The Crosstabulation of the Overall Job Satisfaction versus the Nature of the Work N: 60 (84.5\%) Missing: $11(15.5 \%)$ and the Crosstabulation of the Overall Job Satisfaction Versus Compensations and benefits N: 60 (84.5\%); Missing: 11 (15.5\%) do not have significant Chi-Square significance. The first scores $0.498>0.05$,

41

ISSN 1849-5664 (online) http://researchleap.com/category/international-journal-of-management-science-and-business-administration ISSN 1849-5419 (print) International Journal of Management Science And Business Administration Vol 1. No 3. February 2015., pp. 29-49 
and the second 0.08. Implications: These last two crosstabs did not show a significant correlation with the employee's Job Overall Satisfaction.

\section{Discussion and implications}

\subsection{The patterns of the doctors' satisfaction level}

First of all, it is worth mentioning that the findings regarding the doctors' overall level of satisfaction is of high level. We have put stress on satisfaction and motivation throughout the study. The rationale was to check the correlation between factors causing observed high turnover and the level of satisfaction of the employees relative to the hospitals' management. It is worth mentioning that some doctors can be satisfied with their salary and not with the working environment. They can be satisfied with the job itself, but not with their colleagues and vice versa. This situation has bound us to endeavor deeper concern on the main analytical factors that may enable a better understanding of the problems. For that purpose, we have found relevant to utilize the Job Descriptive Index. All five factors exhibited a correlation relationship with job satisfaction; opportunities for promotion having a strong link, whereas relations with co-workers and attitude toward supervisor exhibited a moderately strong relationship with job satisfaction. Findings imply that discrimination or "playing favorites" should not be exercised. When all things equal, set standards for promotion should be respected grounding the standards for promotion of individuals according to the merit. Furthermore, given the importance of interpersonal relationships for job satisfaction (Adams and Bond 2000), HRM practice aimed at enhancing interpersonal relationship should be strengthened. Our findings that rewards and compensation are positively correlated with job satisfaction confirm a general research notion that high levels of motivational fit are associated with greater job satisfaction, organizational commitment, and lower turnover (O'Connell and Kung 2007). However, the Compensations and benefits lack a significant link with overall job satisfaction, as well as the factors of Nature of the Work. When considering the suggestions given by the doctors regarding what the administration could do to increase their satisfaction, some mentioned lack of compensations, others suggested several job benefits that they wish could be included in the contracts.

\subsection{Best practices for staff retention}

\subsubsection{Increase the rewards and compensations}

Taking the findings of our study into consideration we recommend that Saudi Arabia Southern region hospitals gather their efforts to assess and solve every single factor susceptible of increasing the leavers in the organization. One way of doing so is by increasing the rewards and compensations when the job is well done. In addition, other solutions can be considered, encompassing: compatibility of salary in comparison with the other military hospitals, salary compensation for staying in such remote area, free family

42

ISSN 1849-5664 (online) http://researchleap.com/category/international-journal-of-management-science-and-business-administration ISSN 1849-5419 (print) International Journal of Management Science And Business Administration Vol 1. No 3. February 2015., pp. 29-49 
accommodation and school facilities for the employees' children, more vacation plans, more library and research materials, more seminars, remuneration of the transport fees and the extra working hours, more trained staff and more modern equipment, ongoing training programs (national and international workshops), life insurance benefits and disability benefits package as well as computer system for medical records.

\subsubsection{Increase the communication between organization and employee}

By communication between organization and employee, we mean the social life, the cooperative culture, the professional and friendly relationships between co-workers, and the support from supervisors. Recognizing and encouraging good work is sometimes worth money or bonuses. During the preliminary interviews one respondent stated: "if I do good work, I should be valued even by words; there is a deep gap in communication between the management and the employees". Another respondent condemning the administration's lack of concern towards the employees' social life said: "management needs to work for the benefit of staff and staff for the benefit of the patients unless hospital will be a court not a health facility". Also found to be crucial are staff factors such as staff motivation, cooperation, and attitudes toward innovation (Aarons and Sawitzky 2006). Kim et al. (2009) found that the quality of cooperation and information sharing between network partners are critical factors for hospital network performance. The Sharurah hospitals should view these comments as a caution to increase the communication with the workforce. Because employees are the most valuable assets in the company, satisfying them is visibly a precondition for satisfying the customers. Our study is valuable for the practice as there are implications for the hospitals which may enable them to retain their hospital staff. It is important for the administration department to recognize the root incentives for implementing Employee Satisfaction Program and address the problem of high turnover. Once identified, the program will include exclusively an employee satisfaction survey tailored to understand and meet the unique needs of the hospitals' professionals. Additionally, hospitals can use Employee Entry Surveys which will enable them to identify, in an early stage, their staff's abilities and domains of expertise along with their different expectations and career plans. Human resources managers, in charge of the recruitment, can make use of such programs to gain insights into the motivation and engagement of the interviewees. Organizing welcoming ceremonies, visiting the different departments, explaining the shift hours, and discussing, in detail, the contract's features, bonuses and benefits will also plunge the 'newbies' into an atmosphere of good communication and a motivating starting. This will play as a prerequisite for building a positive image of the organization in the mind of the newly enrolled employee. Similarly, introducing an Employee Exit Surveys would, on the other hand, play as a record of all the perceived factors that would cause the employee's dissatisfaction that have resulted in their decision to leave the organization. Furthermore, Exit Interviews would enable the administration to use information from the employee's report for, first, identifying the ups and downs in the management and thus, make the necessary changes to effectively retain their valuable employees. In the specific case of the Sharurah Hospitals, many doctors complained about the unpaid extra working hours and the transportation fees, while it was indeed included in the job contracts. The employers should consequently reconsider these criteria, for they can

43

ISSN 1849-5664 (online) http://researchleap.com/category/international-journal-of-management-science-and-business-administration ISSN 1849-5419 (print) International Journal of Management Science And Business Administration Vol 1. No 3. February 2015., pp. 29-49 
become disruptive in the long run. To assess and retain their human capital, managers should avoid such conflicts of misunderstandings in order to build a good communication with the employees.

\subsubsection{Review the nature of the work, conduct training and reinforcement}

The administration's ways of distributing the tasks between doctors was identified as one of the most important problems. They seemingly make the dispatching according to the availability of the doctors, not according to their specialties. There is, among the respondents, some who mentioned that there are no nurseries in Sharurah hospital after 4:00 PM. The doctors on duty are obliged to handle such problems without any compensation in return. This situation definitely causes excessive workloads, employee frustration, and negative implications. Management guru Peter Drucker listed four elements that may motivate employees and stimulate satisfaction: careful placement of people in jobs; high standards of performance in the job; provision of worker with the information needed; opportunities for participation in decisions that will give the employee a managerial vision (Drucker 1995). The HR professionals of the SAFH should review the whole system of scheduling the jobs in the different departments. The doctors should be more involved in the dispatching and the decision-makings so that they feel more endowed with responsibility and trust. Internal turnover can bring positive as well as negative effects on doctors who have been transferred into new positions within the same health facility. Everything depends on which motives they have been transferred. Internal turnover will be an opportunity for the employee who aspired to a steady career growth or the one whose morale decreased due to internal conflicts with supervisor or coworker. But it will have negative effects on the employees who encounter a project or a relational disruption resulting from the internal turnover. Management should introduce seminars and training programs both in the national and international scale. We have noticed also that there is a large concentration of foreign doctors in Southern Region hospitals. Their presence can be of great utility to the extent that the local doctors can share experience and knowledge with the foreign doctors. Management should provide enough training and development opportunities to doctors, especially, the newly enrolled ones. These measures can drastically reduce turnover by keeping employees motivated by the chance of enjoying future growth opportunities. Employees are more likely to leave the hospital if they are not given the opportunity to permanently upgrade their experience.

\section{Conclusion and further studies}

Overall our paper tried to make the most use of our proposed solutions in reducing turnover by implementing the best winning retention practices we have found relevant to the case of Southern Region Hospitals.

We emphasize that many issues are at stake when staff retention is not consciously prioritized in the HRM objectives of Southern Region hospitals. The findings can be divided into a twofold type. The first one consists of the observed problems we have pinpointed in the study and the second entails solutions and strategies for increasing doctors' retention. Therefore, Southern region hospital managers should always keep

44

ISSN 1849-5664 (online) http://researchleap.com/category/international-journal-of-management-science-and-business-administration ISSN 1849-5419 (print) International Journal of Management Science And Business Administration Vol 1. No 3. February 2015., pp. 29-49 
in mind that gathering all the efforts possible to satisfy the health professionals is the keystone for gaining customer quality care services.

\begin{tabular}{|c|c|}
\hline Iden & $\begin{array}{l}\text { olutions and strategies to the socio-economic and } \\
\text { geographical context of the SAFH }\end{array}$ \\
\hline $\begin{array}{l}\text { - Hospitals in the Southern Region of Saudi } \\
\text { rates. } \\
\text { - Female doctors are scarce in the region. } \\
\text { - The hospitals face with permanent staff } \\
\text { shortages and instability. } \\
\text { - The region is one of the remotest areas in } \\
\text { the country, rending access to health care } \\
\text { services very difficult. } \\
\text { The doctors in Sharurah Hospitals face } \\
\text { many problems including the lack of } \\
\text { collaboration and communication with the } \\
\text { administration. } \\
\text { Overtime services are not remunerated and } \\
\text { the transportation fees are not reimbursed. } \\
\text { The workforce needs special government } \\
\text { policies that match the realities of the } \\
\text { Southern Region. } \\
\text { The employees lack of training and } \\
\text { - }\end{array}$ & $\begin{array}{l}\text { - The first and most important solution is to } \\
\text { implement winning retention strategies to } \\
\text { discourage turnover in the hospitals. } \\
\text { - Second is that for all people there are more } \\
\text { sustaining motivators than money for } \\
\text { drawing employee satisfaction. However, in } \\
\text { the case of the Sharurah hospitals, salary } \\
\text { increase is one of the most acclaimed } \\
\text { factors for increasing the doctors' } \\
\text { satisfaction. } \\
\text { The other drivers are the extension of the } \\
\text { time vacation, more benefits package, more } \\
\text { training and more consideration and } \\
\text { collaboration from the administration. } \\
\text { In addition to the retention of the best } \\
\text { performers, the recruitment of more } \\
\text { doctors, especially female doctors and } \\
\text { nurses, has become compulsory. } \\
\text { the best winning strategies are the ongoing } \\
\text { rewards and compensations, and the good } \\
\text { - }\end{array}$ \\
\hline
\end{tabular}

\section{Table 6-1 Identified problems and solutions of SAFH}

\subsection{Limitations of the research}

We did not succeed in collecting all the information needed to cover all the issues relative to the topic. For instance, we could not get any annual report from the administration of the hospitals. We did not collect any information regarding the hospitals' annual turnover rates, annual retention rates, staff recruitment programs,

45

ISSN 1849-5664 (online) http://researchleap.com/category/international-journal-of-management-science-and-business-administration

ISSN $1849-5419$ (print) International Journal of Management Science And Business Administration Vol 1. No 3. February 2015., pp. 29-49 
total number of employees and their specialties, just to name a few. This was mainly due to the fact that the targeted hospitals are government-owned organizations. This is to say that providing such confidential information requires a time consuming administrative process. It is noteworthy to recognize that issues related to our topic are of broad spectrum. Indeed, each step of the investigation process can be a subject for more empirical researches. We use this opportunity to incite the Saudi Arabian government and Southern Region hospital decision-makers to have more concern on both management of the hospitals and management of their human resources. The topic emphasized only the retention of doctors but it could be enlarged to the entire workforce. Because employees are the most valuable assets in any company, satisfying them is visibly a precondition for satisfying the customers.

Assessing doctors' retention strategies as solutions for the observed high staff turnover in the Southern Regional hospitals is not a task undertaken by chance. In fact, when people refer to employee retention they do not refer to simply retaining the entire workforce at all. By employee retention we understand the ability and efforts by which an organization succeeds in retaining its best and most valuable employees. In this sense, retention becomes a strategy, not an outcome. The rationale behind this is to make a distinction between the top performing doctors with the low performing ones. Organization should by all means identify what types of employees are leaving Southern region hospitals the most. They must know whom, among the doctors, or the nurses, or the administrative staffs are registering a high frequency of turnover. If it happens that the majority of turnover is among the doctors, then HR managers should consider whether it is the best performing doctors that are leaving or the opposite. The research question requiring further investigation behind this is whether the Sharurah hospitals are capable of replacing the poor-performing doctors with better ones, if they face a problem of staff shortage.

In conclusion, we propose future research should focus on winning strategies for retaining nurses in Southern region hospitals, positive and negative employee job congruity in hospitals, the functional turnover overstated in crisis management and managing the spillover costs of recruitment, retention, and turnover. Hospitals need to pay closer attention to the needs of their human resources especially the doctors in order not to only improve the organization's performances but also to satisfy the demanding population. Last, introducing turnover risk programs and employee satisfaction programs within the hospitals' management schemes have become a necessity. Hospitals, especially in the Southern region, can make use of retention strategies to annihilate the unbalance caused by the doctors' high turnover, thus helping to improve Saudi Arabia health care.

\section{References}


- Achoui, M. M. (2009). Human resource development in Gulf countries: an analysis of the trends and challenges facing Saudi Arabia. Human Resource Development International, 12(1), 35-46.

- Adams, A., \& Bond, S. (2000). Hospital nurses' job satisfaction, individual and organizational characteristics. Journal of advanced nursing, 32(3), 536-543.

- $\quad$ Aiken, L. H., Clarke, S. P., Sloane, D. M., Sochalski, J., \& Silber, J. H. (2002). Hospital nurse staffing and patient mortality, nurse burnout, and job dissatisfaction. Jama, 288(16), 1987-1993.

- Aarons, G. A., \& Sawitzky, A. C. (2006). Organizational climate partially mediates the effect of culture on work attitudes and staff turnover in mental health services. Administration and Policy in Mental Health and Mental Health Services Research, 33(3), 289-301.

- Berhie, G. (1991). Emerging issues in health planning in Saudi Arabia: the effects of organization and development on the health care system. Social Science \& Medicine, 33(7), 815-824.

- Bhuian, S. N., Al-Shammari, E. S., \& Jefri, O. A. (1996). Organizational commitment, job satisfaction and job characteristics: An empirical study of expatriates in Saudi Arabia. International Journal of Commerce and Management, 6(3/4), 57-80.

- Boselie, P., Dietz, G., \& Boon, C. (2005). Commonalities and contradictions in HRM and performance research. Human Resource Management Journal, 15(3), 67-94.

- $\quad$ Brayfield, A. H., \& Rothe, H. F. (1951). An index of job satisfaction. Journal of applied psychology, 35(5), 307.

- Buchan, J., \& Aiken, L. (2008). Solving nursing shortages: a common priority. Journal of clinical nursing, 17(24), 3262-3268

- $\quad$ Bustamam, F. L., Teng, S. S., \& Abdullah, F. Z. (2014). Reward management and job satisfaction among frontline employees in hotel industry in Malaysia. Procedia-Social and Behavioral Sciences, 144, 392402.

- Champathes Rodsutti, M., \& Swierczek, F. W. (2002). Leadership and organizational effectiveness in multinational enterprises in southeast Asia. Leadership \& Organization Development Journal, 23(5), 250259.

- Chaudhury, S., \& Banerjee, A. (2004). Correlates of job satisfaction in medical officers. Medical Journal Armed Forces India, 60(4), 329-332.

- Coomber, B., \& Barriball, K. L. (2007). Impact of job satisfaction components on intent to leave and turnover for hospital-based nurses: a review of the research literature. International journal of nursing studies, 44(2), 297-314.

- Delaney, J. T., \& Huselid, M. A. (1996). The impact of human resource management practices on perceptions of organizational performance. Academy of Management journal, 39(4), 949-969.

- $\quad$ Drucker, P. F. (1995). People and performance: The best of Peter Drucker on management. Routledge.

- Eisenberger, R., Stinglhamber, F., Vandenberghe, C., Sucharski, I. L., \& Rhoades, L. (2002). Perceived supervisor support: contributions to perceived organizational support and employee retention. Journal of applied psychology, 87(3), 565.

- $\quad$ Firth, L., Mellor, D. J., Moore, K. A., \& Loquet, C. (2004). How can managers reduce employee intention to quit?. Journal of managerial psychology, 19(2), 170-187.

- Fisher, C. B. (2003). Goodness-of-fit ethic for informed consent to research involving adults with mental retardation and developmental disabilities. Mental Retardation and Developmental Disabilities Research Reviews, 9(1), 27-31.

- Flap, H., \& Völker, B. (2001). Goal specific social capital and job satisfaction: Effects of different types of networks on instrumental and social aspects of work. Social networks, 23(4), 297-320.

- Florkowski, G. W., \& Schuler, R. S. (1994). Auditing human resource management in the global environment. International Journal of Human Resource Management, 5(4), 827-851.

- Gilles, I., Burnand, B., \& Peytremann-Bridevaux, I. (2014). Factors associated with healthcare professionals' intent to stay in hospital: a comparison across five occupational categories. International journal for quality in health care, 26(2), 158-166.

- Guest, D. (2002). Human resource management, corporate performance and employee wellbeing:

47

ISSN 1849-5664 (online) http://researchleap.com/category/international-journal-of-management-science-and-business-administration

ISSN 1849-5419 (print) International Journal of Management Science And Business Administration Vol 1. No 3. February 2015., pp. 29-49 
Building the worker into HRM. Journal of Industrial relations, 44(3), 335-358.

- Hauff, S., Richter, N. F., \& Tressin, T. (2015). Situational job characteristics and job satisfaction: The moderating role of national culture. International Business Review.

- Hee Yoon, M., Hyun Seo, J., \& Seog Yoon, T. (2004). Effects of contact employee supports on critical employee responses and customer service evaluation. Journal of Services Marketing, 18(5), 395-412.

- Hom, P. W., \& Kinicki, A. J. (2001). Toward a greater understanding of how dissatisfaction drives employee turnover. Academy of Management Journal, 44(5), 975-987.

- Judge, T. A., Piccolo, R. F., Podsakoff, N. P., Shaw, J. C., \& Rich, B. L. (2010). The relationship between pay and job satisfaction: A meta-analysis of the literature. Journal of Vocational Behavior, 77(2), 157167.

- $\quad$ Katsikea, E., Theodosiou, M., Perdikis, N., \& Kehagias, J. (2011). The effects of organizational structure and job characteristics on export sales managers' job satisfaction and organizational commitment. Journal of World Business, 46(2), 221-233.

- Kim, B., Burns, M. L., \& Prescott, J. E. (2009). The strategic role of the board: The impact of board structure on top management team strategic action capability. Corporate Governance: An International Review, 17(6), 728-743.

- Lam, T., Zhang, H., \& Baum, T. (2001). An investigation of employees' job satisfaction: the case of hotels in Hong Kong. Tourism management, 22(2), 157-165.

- Lim, S. (2008). Job satisfaction of information technology workers in academic libraries. Library \& Information Science Research, 30(2), 115-121.

- McAuliffe, E., Manafa, O., Maseko, F., Bowie, C., \& White, E. (2009). Understanding job satisfaction amongst mid-level cadres in Malawi: the contribution of organisational justice. Reproductive health matters, 17(33), 80-90.

- Mellahi, K. (2007). The effect of regulations on HRM: private sector firms in Saudi Arabia. The International Journal of Human Resource Management, 18(1), 85-99.

- Mellahi, K. (2000). Human resource development through vocational education in Gulf Cooperation Countries: The case of Saudi Arabia. Journal of Vocational Education and Training, 52(2), 329-344.

- Ready, D. A., \& Conger, J. A. (2007). Make your company a talent factory. harvard business review, 85(6), 68.

- O'Connell, M., \& Kung, M. C. (2007). The Cost of Employee Turnover. Industrial Management, 49(1).

- Pan, F. C. (2015). Practical application of importance-performance analysis in determining critical job satisfaction factors of a tourist hotel. Tourism Management, 46, 84-91.

- Roxana, A. C. (2013). Social Support as a Mediator Between Emotion Work and Job Satisfaction. Procedia-Social and Behavioral Sciences, 84, 601-606.

- Sarmah, R. K. (2013). A Comparative Analysis of Effectiveness of Training and Development Programme: A Case Study of Multi-Specialty Hospitals.

- Shipton, H., West, M. A., Dawson, J., Birdi, K., \& Patterson, M. (2006). HRM as a predictor of innovation. Human Resource Management Journal, 16(1), 3-27.

- Smith, P. C. (1969). The measurement of satisfaction in work and retirement: A strategy for the study of attitudes.

- Spagnoli, P., \& Caetano, A. (2012). Personality and organisational commitment: The mediating role of job satisfaction during socialisation. Career Development International, 17(3), 255-275.

- $\quad$ Thomas, K. S., Hyer, K., Castle, N. G., Branch, L. G., Andel, R., \& Weech-Maldonado, R. (2012). Patient safety culture and the association with safe resident care in nursing homes. The Gerontologist, gns007.

- Ton, Z., \& Huckman, R. S. (2008). Managing the impact of employee turnover on performance: The role of process conformance. Organization Science, 19(1), 56-68.

- West, M. A., Guthrie, J. P., Dawson, J. F., Borrill, C. S., \& Carter, M. (2006). Reducing patient mortality in hospitals: the role of human resource management. Journal of Organizational Behavior, 27(7), 983-1002.

- Wright, P. M., Gardner, T. M., \& Moynihan, L. M. (2003). The impact of HR practices on the performance of business units. Human Resource Management Journal, 13(3), 21-36. 


\section{Alshahrani Bander Sayaf}

Measuring Job Satisfaction Patterns in Saudi Arabia's Southern Regions Hospitals: Implications for Hospital Staff Retention

- Yousef, D. A. (2000). Organizational commitment: A mediator of the relationships of leadership behavior with job satisfaction and performance in a non-western country. Journal of Managerial Psychology, 15(1), 6-24. 